\title{
Seksuelle bivirkninger av antidepressive legemidler
}

\author{
Seksuell dysfunksjon er vanlig hos pasienter med depresjon. Samtidig \\ kan antidepressive legemidler fremkalle eller forsterke seksuell dys- \\ funksjon som bivirkning. Hvilke antidepressiver er særlig assosiert med \\ seksuell dysfunksjon, og hvilke mekanismer ligger til grunn for slike \\ bivirkninger? Hvordan skal bivirkningene håndteres i klinisk praksis?
}

Se også kunnskapsprøve på www.tidsskriftet.no/quiz

\author{
Joachim Frost \\ joachim.frost@legemidler.no \\ Avdeling for klinisk farmakologi \\ St. Olavs hospital \\ 7006 Trondheim \\ og \\ Institutt for laboratoriemedisin, \\ barne- og kvinnesykdommer \\ Norges teknisk-naturvitenskapelige universitet

\section{Pål Sandvik} \\ Divisjon psykisk helsevern \\ $\emptyset$ stmarka sykehus \\ Olav Spigset \\ Avdeling for klinisk farmakologi \\ St. Olavs hospital \\ og \\ Institutt for laboratoriemedisin, \\ barne- og kvinnesykdommer \\ Norges teknisk-naturvitenskapelige universitet
}

I 1960- og 70-årene kom de første sporadiske rapportene om seksuell dysfunksjon ved bruk av trisykliske antidepressiver og monoaminoksidasehemmere (1). I 1980- og 90-årene ble flere nye grupper antidepressive legemidler introdusert, blant annet selektive serotoninreopptakshemmere (SSRI) og serotoninog noradrenalinreopptakshemmere (SNRI). Med disse nye midlene fulgte en økning i rapporteringen av seksuelle bivirkninger, særlig ved bruk av SSRI-preparater (2).

Målet med denne artikkelen er å beskrive fenomenet seksuell dysfunksjon som bivirkning av antidepressiver og å gi en praktisk veiledning i hvordan bivirkningen kan håndteres.

\section{Materiale og metode}

Artikkelen bygger på relevant materiale funnet ved ikke-systematiske søk i Medline og forfatternes kliniske erfaringer.

\section{Mekanismer}

Ifølge den internasjonale sykdomsklassifikasjonen ICD-10 vil seksuell dysfunksjon innebære en forstyrrelse $i$ en eller flere av fasene som karakteriserer seksuell respons. Lyst (libido) ledsages av motivasjon for seksuell aktivitet. Dette er i det vesentlige styrt av økt dopaminerg aktivitet i baner til nucleus accumbens og hypothalamus, mens serotonin har en negativt modulerende effekt. Opphisselse ledsages av fysiologiske endringer som ereksjon og vaginal lubrikasjon. Effektene medieres trolig fra hypothalamus via det parasympatiske nervesystemet og reguleres hovedsakelig av acetylkolin og nitrogenmonoksid (NO). Også her har serotonin en negativt modulerende effekt. Orgasme (og ejakulasjon hos menn) effektueres via økt aktivitet i sympatiske noradrenerge baner, mens økt aktivitet i serotonerge baner virker hemmende.

Serotonerge midler som SSRI- og SNRIpreparater vil således både kunne redusere libido og virke negativt på opphisselse og orgasme/ejakulasjon. Seksuell dysfunksjon utløst av serotonerge midler kan dermed oppstå i flere faser av den seksuelle responssyklusen, også hos en og samme pasient (3). Det ser imidlertid ut til å være noe vanligere med forsinket eller manglende orgasme enn med nedsatt libido (2).

\section{Forekomst}

Alt i alt er forekomsten av seksuelle bivirkninger anslagsvis $40 \%$ ved bruk av SSRIpreparater, mot $10 \%$ ved placebo (2). Det finnes få studier som har sammenliknet frekvensen av seksuelle bivirkninger hos ulike SSRI-preparater. En gjennomgang fra 2008 konkluderte med at det ikke foreligger sikre holdepunkter for at noe SSRI-preparat har færre seksuelle bivirkninger enn andre, selv om det finnes visse data som antyder at slike bivirkninger er vanligere ved paroksetin enn ved andre midler i gruppen (4).

Overveiende noradrenerge antidepressiver som nortriptylin, reboksetin, mianserin og mirtazapin har en mer nøytral effekt på seksuell funksjon. Dertil kommer at mianserin og mirtazapin har en serotonin 2A-resep- torblokkerende effekt som reduserer mulige ugunstige serotonerge effekter. Det finnes imidlertid ikke gode studier der man direkte sammenlikner disse midlene med SSRImidler med hensyn til forekomst av seksuelle bivirkninger.

Bupropion, som er et dopaminergt og noradrenergt antidepressivt middel, er ikke vist å ha negative effekter på libido eller orgasme, og frekvensen av seksuelle bivirkninger er på nivå med placebo (2).

De ulike antidepressivenes antatte potensial til å gi seksuelle bivirkninger er fremstilt skjematisk i figur 1.

\section{Praktisk håndtering}

Pasienter med depresjon vil ofte kunne akseptere nedsatt seksuell funksjon i akuttfasen, men ved langtidsbehandling kan seksuelle bivirkninger nedsette livskvaliteten betydelig. Det er derfor viktig å identifisere bivirkningene og iverksette tiltak slik at pasienten ikke selv seponerer behandlingen.

Mange mennesker synes det er vanskelig å diskutere seksuelle spørsmål med andre, også med leger og andre helsearbeidere. Man kan således ikke forvente at pasienter spontant vil rapportere seksuelle bivirkninger. Det vil derfor være nødvendig at legen tar opp problemstillingen og stiller konkrete spørsmål i en språkform som pasienten forstår.

Det bør gjøres en kartlegging av hvordan seksuell funksjonsevne var før behandlingsstart (helst både før og etter sykdomsdebut), eventuell psykiatrisk og somatisk komorbiditet (diabetes, arteriosklerose, nevrologisk

\section{Hovedbudskap}

- Seksuelle bivirkninger forekommer hos anslagsvis $40 \%$ av alle som behandles med selektive serotoninreopptakshemmere eller andre serotoninaktive midler

- For noradrenalin- og dopaminreopptakshemmeren bupropion er forekomsten av seksuelle bivirkninger på samme nivå som for placebo

- Tilleggsbehandling med bupropion eller bytte til mirtazapin eller bupropion kan være en effektiv strategi

- Tilleggsbehandling med sildenafil eller tadalafil har en dokumentert positiv effekt, men bare hos menn 
og endokrinologisk sykdom), psykososiale forhold (ekteskapsproblemer etc.), rusmiddelbruk (inkludert røyking) og bruk av andre legemidler $(1,5)$. Andre legemidler med seksuell dysfunksjon som kjent bivirkning omfatter blant annet antipsykotika, betablokkere, tiaziddiuretika, antiandrogener og antiøstrogener.

Det er foreslått en rekke ulike behandlingsstrategier ved seksuell dysfunksjon utløst av antidepressiver (ramme 1). Valg av strategi vil avhenge av pasientens kliniske situasjon.

$\AA$ avvente spontan remisjon eller toleranseutvikling vil kunne være uakseptabelt for pasienten og er rapportert som lite effektivt (2). Identifisering av minste effektive dose av det antidepressive legemidlet er generelt et godt prinsipp, og siden de seksuelle bivirkningene ser ut til å være doseavhengige, er dette anbefalt også i denne sammenheng (3). Det krever imidlertid nøye og kontinuerlig monitorering av de depressive symptomene for å påvise en eventuell begynnende sykdomsforverring, og metoden kan være risikabel hvis ikke dosereduksjonen skjer svært langsomt.

Dosering én gang daglig og planlagt seksuell aktivitet rett før neste legemiddelinntak har også vært foreslått $(2,3)$. Det foreligger begrenset kunnskapsgrunnlag for nytten av en slik strategi, men det kan eventuelt forsøkes for SSRI-preparater med de korteste halveringstidene, slik som paroksetin (15-30 timer) og sertralin (22-36 timer). Likevel er halveringstiden også for disse midlene såpass lang at man ikke kan forvente noen dramatisk effekt. I tillegg krever dette at den seksuelle aktiviteten til en viss

\section{Ramme 1}

\section{Mulige behandlingsstrategier ved seksuell dysfunksjon forårsaket av antidepressiver}

Avvente spontan remisjon eller toleranseutvikling

Dosereduksjon for å identifisere minste effektive antidepressive dose

Dosering én gang daglig og planlegging av seksuell aktivitet til tiden rett før neste legemiddelinntak ${ }^{1}$

Kortvarig seponering, for eksempel i forbindelse med helger ${ }^{1}$

Tilleggsbehandling med et legemiddel som motvirker de seksuelle symptomene

Bytte til et antidepressivt middel som i mindre grad er assosiert med seksuell dysfunksjon (jf. fig 1)

${ }^{1}$ Gjelder legemidler med kort halveringstid, som paroksetin og sertralin

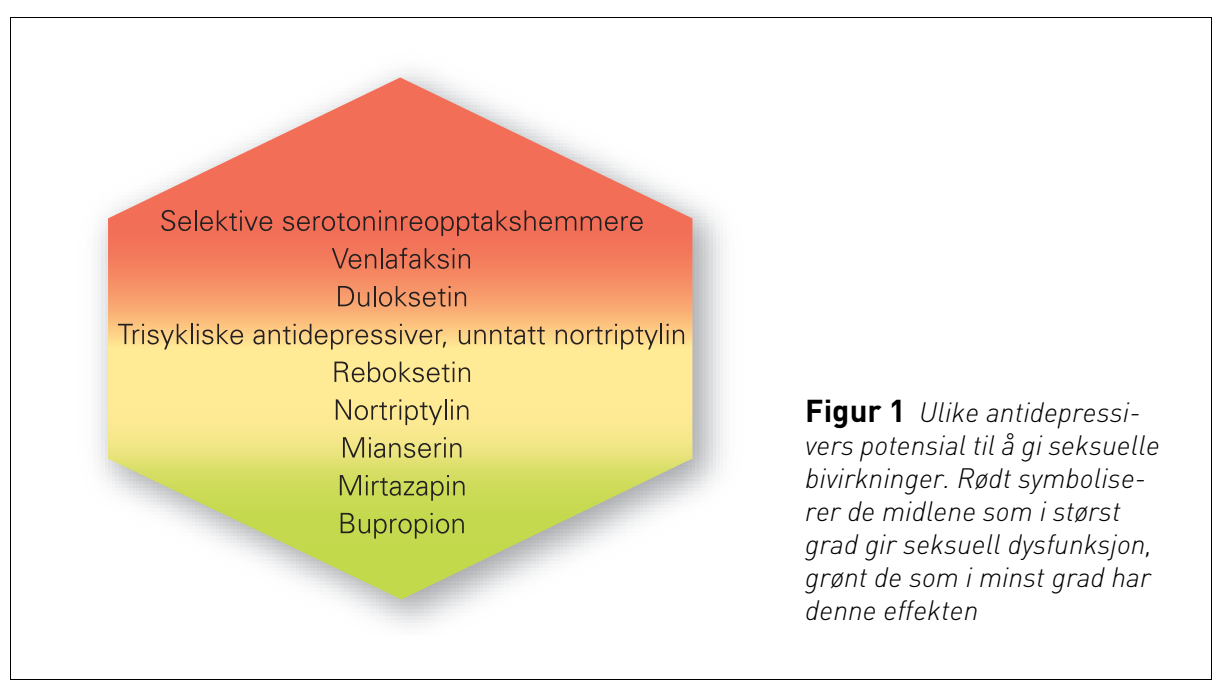

grad må planlegges på forhånd, noe som ikke alltid er ønskelig.

Ved seponering eller dosereduksjon i 2-3 påfølgende dager (drug holidays) og planlagt seksuell aktivitet mot slutten av perioden, har man i én studie rapportert suksess ved bruk av SSRI-midler med relativt kort halveringstid (6). Dette krever imidlertid tett oppfølging på grunn av risikoen for seponeringssymptomer. Det har også vært spekulert i om en slik håndtering kan invitere til dårligere etterlevelse (1).

Gitt som tilleggsbehandling har tre legemidler vist seg å ha effekt $\mathrm{i}$ randomiserte kontrollerte studier, sildenafil, tadalafil og bupropion $(7,8)$. For sildenafil og tadalafil har man sett tilsvarende effekt ved antidepressivumutløst seksuell dysfunksjon som ved seksuell dysfunksjon av andre årsaker. Selv om disse midlene i prinsippet kun stimulerer ereksjonen og forutsetter normal libido, har man i kliniske studier også sett positive effekter på libido $(7,8)$. Studiene er kun utført hos menn. Tilleggsbehandling med bupropion har vært forsøkt i ulike regimer. I en åpen studie hadde en av tre pasienter nytte av enkeltdoser på 75-150 mg 1-2 timer før samleie (9). Det ble sett effekt både på libido, ereksjon/lubrikasjon og orgasme/ ejakulasjon. I kontrollerte studier er det imidlertid først når man har gitt $150 \mathrm{mg} \times 2$ som kontinuerlig, daglig behandling at man har kunnet påvise noen effekt $(7,8)$. Ved kombinasjonsbehandling med bupropion må man være oppmerksom på risikoen for legemiddelinteraksjoner, siden bupropion er en kraftig hemmer av leverenzymet CYP2D6.

Selv om en rekke andre midler, blant annet mirtazapin, i kasuistikker og åpne studier er vist å ha effekt, har man ikke kunnet påvise noen effekt av slik tilleggsbehandling $\mathrm{i}$ placebokontrollerte studier $(7,8)$. Imidlertid har mange av studiene vært små og har dermed delvis hatt for liten styrke til å kunne påvise eventuelle forskjeller.

Å bytte til et antidepressivt middel som i mindre grad er assosiert med seksuell dysfunksjon (fig 1) vil i mange tilfeller være effektivt $(2,3)$. Det finnes noe data på bytte til bupropion (10), og i en ukontrollert studie fikk to av tre pasienter bedring eller remisjon av seksuell dysfunksjon ved bytte til mirtazapin (11). Det kan eventuelt også være et alternativ å bytte til et annet noradrenergt middel, som mianserin eller nortriptylin. À bytte fra ett SSRI-preparat til et annet kan ikke forventes å ha noen effekt (3).

Oppgitte interessekonflikter: Pål Sandvik har i løpet av de siste fem årene mottatt kongresstøtte fra Wyeth og Astra Zeneca. De øvrige forfatterne har ingen oppgitte interessekonflikter.

\section{Litteratur}

1. Balon R. SSRI-associated sexual dysfunction. Am J Psychiatry 2006; 163: 1504-9.

2. Gregorian RS, Golden KA, Bahce A et al. Antidepressant-induced sexual dysfunction. Ann Pharmacother 2002; 36: 1577-89.

3. Woodrum ST, Brown CS. Management of SSRIinduced sexual dysfunction. Ann Pharmacother 1998; 32: 1209-15

4. Grudén S, Hallberg P. Är något SSRI-preparat att föredra när det gäller sexuella biverkningar? Läkartidningen 2008; 105: 1949

5. Gitlin MJ. Psychotropic medications and their effects on sexual function: diagnosis, biology, and treatment approaches. J Clin Psychiatry 1994: 55 : 406-13.

6. Rothschild AJ. Selective serotonin reuptake inhibi tor-induced sexual dysfunction: efficacy of a drug holiday. Am J Psychiatry 1995; 152: 1514-6.

7. Rudkin L, Taylor MJ, Hawton K. Strategies for managing sexual dysfunction induced by antidepressant medication. Cochrane Database Syst Rev 2004; nr. 4: CD003382.

8. Taylor MJ, Rudkin L. Hawton K. Strategies for managing antidepressant-induced sexual dysfunc tion: systematic review of randomised controlled trials. J Affect Disord 2005; 88: 241 -54.

9. Ashton AK, Rosen RC. Bupropion as an antidote for serotonin reuptake inhibitor-induced sexual dysfunction. J Clin Psychiatry 1998; 59: 112-5.

10. Clayton AH, McGarvey EL, Abouesh Al et al. Substitution of an SSRI with bupropion sustained release following SSRI-induced sexual dysfunction. J Clin Psychiatry 2001; 62: 185-90.

11. Gelenberg AJ, McGahuey C, Laukes C et al. Mirtazapine substitution in SSRI-induced sexual dysfunction. J Clin Psychiatry 2000; 61: 356-60. 